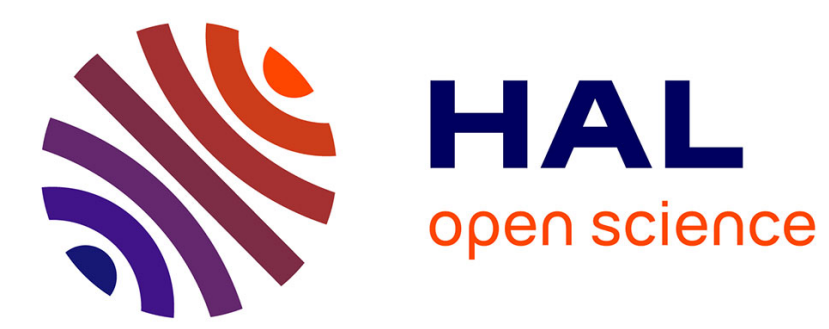

\title{
Urban governance of megacities : searching for the collective actor
}

Christian Lefèvre

\section{To cite this version:}

Christian Lefèvre. Urban governance of megacities: searching for the collective actor. Handbook of megacities and megacity-regions, In press. hal-03177793

\section{HAL Id: hal-03177793 \\ https://hal.science/hal-03177793}

Submitted on 23 Mar 2021

HAL is a multi-disciplinary open access archive for the deposit and dissemination of scientific research documents, whether they are published or not. The documents may come from teaching and research institutions in France or abroad, or from public or private research centers.
L'archive ouverte pluridisciplinaire HAL, est destinée au dépôt et à la diffusion de documents scientifiques de niveau recherche, publiés ou non, émanant des établissements d'enseignement et de recherche français ou étrangers, des laboratoires publics ou privés. 


\section{Chapter : Urban governance of megacities : searching for the collective actor}

Urban governance has been particularly a focus of many academic research and many policy reports of various international organizations (OECD, European Commission, UN-Habitat, etc.) in the two last decades. This is so because it is only by tackling this question which involve a better coordination and coopeation between players that it will be possible to produce efficient and effective policies to address the challenges and issues facing cities today. This would be all the more true for megacities whose system of players could be considered more complex than in other types of urban areas. Here, as in other large metropolitan areas ${ }^{1}$, the key point is the capacity of a system of players to produce collective action and it is this capacity which is analyzed in this chapter.

At least four processes (globalization, decentralization, liberalization and European integration,) which have touched most countries and cities have deeply transformed the economy and societies of megacities. One of the main effects of such changes have been the multiplication of players who intervene in cities : global firms, citizens councils, third sector associations, quangos have flourished and have been added to existing local governments, business organizations and others. The larger the megacity, the larger the number of actors involved in their governance. The result has been the production of a complex system of governance whose capacity to act has been questioned (section 1).

The chapter will investigate several issues particularly crucial for the governance of megacities (e.g. metropolitan aras of 10 million people or more). First, the place and role of the State which in spite of the globalization and decentralization processes remains and will remain a powerful player (section 2). Second the emerging and arguably increasing role of firms, and notably international and global firms, in the definition of the orientation of future developments, notably through their involvement in the making of megacities' strategies and policies (section 3). Third, the place devolved to the population of these megacities in their governance and notably in their political decision making system (section 4).

\section{Four processes which shape the governance of megacities}

Four important processes have shaped the governance of megacities in the last decades, namely globalization, decentralization, increasing liberalization (deregulation and privatization) and European integration, this last one being particular to European cities only.

\subsection{Globalization and how it affects cities and their governance}

The first impact of globalization on the governance of megacities concerns the role of the State which we identify as the central state in unitary countries and Federal state or federate units (States in the US, Brazil, India, Provinces in Canada, Lander in Germany, etc.) in Federal countries . As we shall see, the State remains an important player but the globalization process has significantly changed its role and place. The State is no longer the unique center of collective action; it has to deal with a more pluralistic system of players in which traditional players (such as local governments) are gaining importance and new actors are emerging. Among these new actors, one can mention some international organizations, like the European Union (cf. below), the OECD or the World Bank which intervene in the governance directly through specific funding or with strong recommendations (OECD, 2001, 2015) ; Global firms, notably in the sectors of finance, utilities, services and the new economy developped by digital platforms (Airbnb, Uber, etc.) ; but also international NGOs and social

\footnotetext{
${ }^{1}$ The OECD defines 'functional economic units' on the basis of population density and travel to work flows aggregating densely inhabited 'urban cores' and 'hinterlands' whose labour market is highly integrated with the core. Using this definition, OECD has identified 1148 Functional urban regions in its 28 member countries ; 74 of them are large metropolitan areas (i.e. over 1.5 million) (OECD, 2012)
} 
movements. With globalization, the system of players has become more polycentric and more complex.

It has also become more conflictual, notably because the new actors have brought new issues and new stakes which challenge the interests of local players and because the capacity to regulate conflicts, previously often done by the State, has diminished. For instance, globalization has often been interpreted by some players as a necessity to develop policies aiming at better positioning the city in the world competition. To do so, these players have strongly pushed for putting competitiveness and attractiveness as a top priority with respect to other issues (such as social or environmental problems). In a period when public funding is becoming scarce, there has been a conflict between these interests about the priority of funding infrastructures and amenities, such as building new airport connections (extremely important for the global accessibility of a territory) to the detriment of the improvement of local public transport (extremely important for the quality of life of urban residents); the same is true regarding housing where the introduction of digital platforms such as Airbnb has disrupted an already very tight market to the benefit of some landlords and tourists (notably international tourists) and to the detriment of most local residents, heightening conflicts between the use value and the exchange value of the city.

Finally globalization has affected the governance of cities by introducing new challenges but also by giving them new resources. With globalization, there is no doubt that cities - some cities at least and mostly megacities - have been the locus of new movements of people and of activities that have significantly altered their societies and have required new behaviours. This is for instance the case of migrations whose persons primarily settle in big cities and consequently transform their social, economic but also political societies. The challenges brought by immigration in terms of multiculturalism and cosmopolitanism may not be that new but their extent and their acceleration is definitely a new phenomenon that cities must accommodate. And in terms of behaviour, this has been more and more important with the notions of tolerance of ethnical diversity considered - at least in some cities such as London, Madrid, New York or Toronto - new assets in the global competition.

In addition, globalization has put cities at the forefront of several world-wide if not planetary issues. If they are the receptacles of many global challenges such as migrations and climate change, they are also - or they can be - the agents who will address and solve these challenges. In order to do so, they are entering the international arena by building transnational networks (like C40) and by pursuing specific policies to tackle these new issues. This transnationalisation of cities has given them new political resources which help them to pursue their own policies and in many instances to challenge the States who have chosen a different path such as the USA with the Trump administration and the United Kingdom with Brexit. In so doing, their governance is being internationalized.

\subsection{Decentralization and how it affects urban governance}

Decentralization has been significant in recent decades, even in the most centralized countries like France, Japan or South Korea where decentralization laws have been implemented. This process has been organized through a transfer of State powers and resources to local governments in all dimensions ; fiscality, competences, staff, etc. This has significantly increased the power of local governments which have gradually acquired more autonomy vis a vis the States with a real capacity of expertise in many domains and a stronger political legitimacy, all the more when these authorities have been run by executives directly elected by the voters.

In fact, many reforms have been introduced in that respect and have significantly helped to produce local leadership, notably in several megacities. Big mayors have emerged as in Berlin, London, New York, Rome, Seoul or Tokyo because they are directly elected but also in several other cities where the electoral system has permitted the emergence of political leadership like in Paris, Madrid, or Barcelona. 
If these decentralization trends have had positive effects on local governments and notably on central cities, they have also increased the difficulties of governing the metropolitan territory. Indeed, most metropolitan areas are composed of a multitude of local governments whose territories represent only a small portion of the whole city (table 1 ).

Table 1 : number of municipalities and fragmentation index in some megacities, using the OECD definition of 'metropolitan areas'

\begin{tabular}{|l|r|r|}
\hline & $\begin{array}{c}\text { Number of local } \\
\text { governments }\end{array}$ & $\begin{array}{c}\text { Fragmentation } \\
\text { Index* }\end{array}$ \\
\hline Los Angeles & 169 & 1.03 \\
\hline London & 47 & 0.42 \\
\hline Mexico & 55 & 0.30 \\
\hline New York & 356 & 2.17 \\
\hline Paris & 1,375 & 12.09 \\
\hline Seoul & 965 & 4.56 \\
\hline Tokyo & 235 & 0.69 \\
\hline
\end{tabular}

*Fragmentation index : number of local governments for 100,000 inhabitants : the higher it is, the more fragmented is the metropolitan area

Source : OECD metropolitan areas data base

For example, the Paris area contains no less than 1,375 municipalities, New York about 3,000 local authorities, if other types of local governments (counties, special districts, etc.) are included (RPA, 2017). The larger the metropolis, the more numerous are local governments. This institutional fragmentation has been considered by many as one of the major obstacles for metropolitan governance and one of the main objectives for institutional and territorial reforms (Lefèvre, 1998). Cooperation and coordination are therefore needed to produce collective action and policies. Although this has already been difficult with so many local authorities, it has become all the more problematic when those governmental units have gained power and resources. This is so because these governmental units have rarely accepted to share those new powers with other authorities which is what is implied in cooperation and policy coordination. With decentralization, the governance of metropolitan areas has definitely been more arduous, all the more since most institutional and territorial reforms have failed to establish strong metropolitan authorities (Lefèvre, 1998 and 2012) and have instead reinforced the existing institutional players.

\subsection{Privatization, deregulation and neo-liberalism}

In the 1980s, a series of liberal policies were launched in many countries. The United States and the United Kingdom were at the forefront with the so called Reaganomics and the Conservative Revolution of M. Thatcher and they were soon followed by other countries. The key words were privatization and deregulation which were supposed to bring efficiency, innovation, reduction of costs in public services and policies. The objective was to reduce the importance of the State and more generally of public authorities and agencies and to transfer part of this power to the private sector.

Cities were largely hit by these measures which touched important economic sectors like telecommunications, transport (public transport notably), energy, infrastructure (airports, railroads) and many urban services, notably the utilities. The major impact on the governance of cities was to give more power to private firms in the provision and delivery of services to the people but also in the production of urban development. One iconic example was the creation of urban development corporations in the UK whose main activities were to regenerate portions of central cities (notably the Docklands area in London) and where the private sector was in charge along with the State but where local governments were marginalized. Besides giving more power to private firms, one of the major consequences was also to legitimize the role of the private sector in the governance of metropolitan areas, notably in London (Travers, 2003). 
Despite many criticisms, the most notable being the claim that these policies have paved the way for the production of a neo-liberal city (Moulaert and al, 2003 ; Pinson and Morel-Journel, 2017), most of these policies have been pursued, notably in megacities of the South. This long trend of privatization and deregulation has thus reinforced the place and role of the private sector in the governance of metropolitan areas.

\subsection{European integration}

For European cities another process has had a strong impact on their governance : European integration. Indeed, the transfer of significant State powers (currency, justice, etc.) to the European Union has forced cities to accept the introduction of additional legal rules and regulations in the ways they deliver and operate services and produce and implement public policies; new norms of production, new obligations have been introduced like for cities to comply with EU regulations regarding the openness of some urban services to competition with non national operators, notably private ones. This has been for instance the case for urban transport. In cities where several urban services had been previously publicly controlled and publicly produced like in Austria, Germany or Italy, this has meant a significant change. In addition, although cities have gained some new resources coming from EU subsidies (such as those provided by the Structural Funds), these resources have been made available in exchange for respecting specific rules. In many instances these rules have had a strong impact on the governance of cities such as the obligation for citizen participation in urban development projects.

The new resources provided by the EU to cities have allowed them some flexibility in their policy making by giving them more autonomy vis-a-vis their respective States since they have been able to find additional resources outside the national framework. The European integration process has also helped to furnish cities with additional cognitive and operational elements, notably in policy making. This has been largely done through the proliferation of European urban networks where cities have been able to learn from each other and to exchange ideas and experiences in many policy fields such as transport, immigration, economic development, innovation, skills, environment, etc. Indeed, many cities have benefited from networks initiated and partly funded by the European Commission such as Urbact in which the governance aspects of policy making have been significant.

As a whole these four processes have largely contributed to change the governance system of megacities. Players have become more numerous and more diversified, the system has become polycentric with a necessity to establish cooperation between players often bearing different if not conflicting interests. New challenges have appeared while some existing problems have not been solved. The production of collective action has therefore become more difficult.

\section{The importance of States in the governance of megacities}

The importance of States in the governance of megacities is to be seen in almost every country of the world where such megacities exist. This importance does not depend primarily on the nature of the political regime, be it a democracy or a dictatorship, because we find the State's presence in both regimes albeit in a very different way. It does not depend either on the constitutional nature of the country, be it unitary or federal, because we find the State's presence in both types of countries. However, while the role of the central State will be significant in unitary countries, it will be the federate units which will intervene more strongly in urban affairs in federal countries, the Federal level being less present.

In an apparent paradox, both processes of globalization and European integration have not reduced the importance of the State. Some scholars (Brenner, 2004) have well substantiated the role of the State in the globalization process and other authors (LeGalès, 2011) have done the same regarding European integration. Indeed, the State has been a powerful actor in political rescaling and in the development of neo-liberal policies in some countries. It has been an active agent of the European integration process 
as well. However, in doing so, the nature of its intervention and presence has changed. Contrary to previous analyses which had interpreted these changes as the 'hollowing out of the State' (Rhodes, 1994), it is more a 'reconfiguration' of its role and place that we have seen, i.e. a relative withdrawal of its direct intervention and a more 'arm's length government' ('gouvernement à distance') (Epstein, 2009). through the setting of rules and norms, conditioned by State's money. In addition to this, the 2008 financial crisis has shown that States were still important, if not central, in mitigating such situations.

The State's presence in the governance of megacities depends on the degree of decentralization of the country. If decentralization ${ }^{2}$ has been a trend in the last decades, its importance varies according to the country. However, in general terms it can be said that the State's involvement in urban governance will be stronger in countries where decentralization is weak (in spite of recent decentralization laws) like France, Japan, Portugal, South Korea or UK and less significant in nations where this process has been well established like Italy, Spain, Sweden or Switzerland.

The reasons why the States, whatever their constitutional forms and whatever their modes of intervention, remain important in the governance of megacities is easy to understand. First, megacities represent a significant societal stake because of their national demographic and economic weight (table 2) and the social and environmental challenges they face.

Table 2 : Demographic and economic weigh of some megacities, using OECD definition of 'metropolitan areas'

\begin{tabular}{|l|r|r|r|}
\hline & Population 2014 & \% national population & \% national GDP \\
\hline Istanbul & 15.0 & 18.5 & 49 \\
\hline London & 12.4 & 19.3 & 28 \\
\hline ÒMexico & 20.4 & 17.1 & 23 \\
\hline New York & 16.7 & 5.2 & 8 \\
\hline Paris & 12.0 & 18.8 & 31 \\
\hline Sao Paulo & 13.1 & 6.2 & 22 \\
\hline Seoul & 24.9 & 49.5 & 46 \\
\hline Tokyo & 36.0 & 28.3 & 32 \\
\hline
\end{tabular}

Source : OECD, metropolitan areas data base and IMF, country data

Second, megacities can be political rivals of States, all the more if they can gain more political and financial autonomy which would give them the capacity to challenge States' policies and power. This political rivalry can be all the more dangerous for the State when these megacities are also the national capitals, which is often the case. In addition, the importance of their electorate make them more important and no national governments would be happy to see their megacities controlled by opposite parties and historical examples are many regarding the political conflicts between national capitals and megacities - and their national governments. This was the case with London and all British metropolitan areas during the Thatcher period and it is the case today with the Brexit; New York today with the Republican new administration, Tokyo, etc. are also good examples of such conflicts.

The logic behind these potential conflicts is the necessity for the State to avoid a political rivalry with their megacities. It is therefore important for national governments to limit the autonomy of national capitals and megacities, all the more when this autonomy could be used to implement policies which would be different, if not opposed, to the national ones. Therefore, it is clear that, considering the importance of megacities for the social, economic and political development of the country, the State cannot be unconcerned by their governance and as such must be involved in it.

\footnotetext{
${ }^{2}$ It is always tricky to generalize when discussing the issue of Decentralization since this process is multidimensional and includes elements of finance, political power, responsibilities, etc. As such, one country may be more decentralized in one dimension and less decentralized in another.
} 
One important dimension of this involvement is the fact that States have the authority to set up laws, rules and norms which establish the institutional (political as well as financial) organization of the megacity which may or may not be treated differently from other metropolitan areas in the country (Kubler and Lefèvre, 2018). London, for example, has always been treated separately from other metropolitan areas of Great Britain and national legislation has been decisive in regulating London's institutional framework, in 1963, 1986 and most recently in 1999 and 2007 with the Greater London Authority Acts. In France, Paris has always received a special treatment by the national government, with specific legislation on its institutional system at least since the end of the $19^{\text {th }}$ century with the abolition of the mayoral function only restored in 1977; this special treatment has been true even until recently with the Metropolitan Act of 2014 and the decentralization Act of 2015. In Istanbul as well, the institutional setting imposed by national legislation on Metropolitan Municipalities, introduced in 1984 and revised in 2004, had a major impact on the system of governance of the Turkish megacity. In the United States, New York City very much depends on the federate State of New York for its fiscal system and institutional powers. Seoul, the capital of South Korea has been granted the specific status of 'special city' by national law, etc.

In addition, states very often contribute significantly to the general budget of authorities in megacities. In London, most of the budget of the Greater London Authority (GLA) comes directly or indirectly (e.g. through a grant to Transport for London) from the national government. In New York, the New York State contributes to the financing of policy sectors such as education or social aid. The assistance of the State is also essential for the massive investments needed to build the many facilities and infrastructures necessary for the development of megacities, notably in domains like transport, energy, telecommunications, and airports. In Istanbul, the Marmara Project (train tunnels under the Bosporus) or the building of a third bridge over the Bosporus heavily depends on national funding and state guarantee for international loans. In London, Crossrail, the most important train infrastructure linking the east and west of the megacity region will be partly funded by the national government. In Paris, the New Greater Paris network of public transport, which includes the $220 \mathrm{~km}$ subway network Greater Paris Express, will also be partly supported by the national government. In India, the metropolitan subway networks of Delhi or Mumbai are also heavily dependent upon financial contributions of the federate states (Kübler and Lefèvre, 2018).

But states are also heavily involved in everyday policy-making in megacities. First through their administrative structures at the local or regional levels. This is the case in the Paris region where the regional prefect, a representative of the State, detains strong powers over the capital region. In Mumbai, the city is ruled by the Mumbai Corporation of Greater Mumbai whose principal executive is the municipal commissioner appointed by the federate state of Maharashtra (Zérah, 2014). The presence of the national government is particularly strong in several China's megacities, not only in the four centrally administered cities (Beijing, Shanghai, Tianjin, Chongqing) but also in cities like Guangzhou and Shenzhen, whose governance arrangements in the Pearl River Delta denote a pattern of 'state-led metropolitan governance' (Ye, 2014). In addition, central and federate states often control political and administrative resources crucial for the development of megacities through their regional (de-concentrated) branches of the public administration,.

Second, central and federate states (e.g. States in the US, Provinces in Canada) also intervene in the governance of megacities through their public enterprises, corporations or agencies in several policy fields such as planning, transport, energy, telecommunications, housing, etc. In New York, the Empire State Development Corporation, entirely controlled by the State of New York, is a key player in urban development, housing and economic development. A very large part of the transport network of this megacity (airports, public transports, bridges, tunnels and ports) is managed and operated by the Port Authority, a body jointly controlled by the states of New York and New Jersey. In Paris, the two major transport agencies (RATP for buses and metros and SNCF for the national railroads) are controlled by the central Government. More recently, the State established a new corporation, the Greater Paris Corporation (Société du Grand Paris) to build the Greater Paris Express and this new corporation is controlled by the State which has the majority of seats in its board. In Mumbai, the Mumbai Metropolitan Region Development Authority, the most important agency in charge of metropolitan 
development, is totally controlled by the State of Maharashtra. In Delhi, the Delhi Metrorail Corporation, in charge of building and managing the metro, is a joint venture between the National Government of India and the Government of the National Capital Territory of Delhi, a sub-national authority specific to the capital of India. In Istanbul, Toki, one of the most important urban developers, is a national corporation depending on the national ministry of housing. In the Sao Paulo megacity, public transport is entirely looked after by agencies under the control of the government of the federate state of São Paulo.

Finally, states intervene in megacities in the field of strategic planning. In Paris, the regional master plan, aiming at the design of the future spatial development of the megacity, must be approved by the national government which is also involved in its elaboration. Furthermore, the national government also controls several public development corporations on so-called operations of national interest (Opérations d'Intérêt National) in areas which it considers of national importance for the development of the Paris region and on which it has established specific development plans. In the Delhi area, more than 30 special economic zones (SEZ), a key tool for the territorial development of the urban area, have been set up by the state since 2005. These SEZ are vast delineated areas which enjoy a special juridical and fiscal status in order to attract investment and development (Bon and Kennedy, 2018). Another example of central government strategic involvement in the governance of megacities is in Tokyo or Seoul. In both areas, the States intervene via national Plans (in Tokyo a national plan for the Capital Region (a bit larger than the Tokyo metropolitan area) and in Seoul a national strategic plan which serves as the reference to all local plans for the development of the Seoul region), denoting the continuing importance of the developmental State (Saito, 2012).

\section{Private economic players : an increasing role in the governance of megacities?}

Private economic players have always been involved either directly or though their associations in the governance of cities, at least in capitalist countries. Growth coalitions (Logan, and Molotch, 1987) or urban regimes (Stone, 1993) which are some forms of public-private arrangements of urban governance have been identified in some urban areas in the last decades. However, what is often presented as new or recent is the increasing place and role of private firms in this governance. The financialization process of urban development (Halbert and Attuyer, 2016), the more visible presence of big firms, notably global firms and more recently digital platforms like Uber or Airbnb, in the provision and/or delivery of urban services have induced a number of scholars, journalists and politicians to denounce the production of a neo-liberal city, controlled by private interests sometimes in close relations with public authorities, including central states.

If there seems to be a more visible involvement of the private sector in the governance of some cities (London and the British urban areas being examples often cited) in the world, it remains to analyse whether this is recent, whether their role is increasing and whether this can be generalized to most cities of the world. If the literature regarding the neo-liberalization of cities is abundant (Peck and Tickell, 2002; Brenner, Peck and Theodore, 2010), it very often remains general regarding the stronger presence and importance of the private sector in their governance. Here, we need more empirical works and more comparative studies to be able to state that the production of urban development is following a neo-liberalist path as it is questioned in several academic production (Le Galès, 2016 ; Pinson and Morel-Journel, 2017) ${ }^{3}$.

Private firms are sometimes directly involved in the governance bodies of megacities. This is for instance the case of London where business participates in many organizations and agencies in charge of the promotion of London or its development strategies and policy implementation. London and Partners, the inward agency of the British capital, is a public-private partnership which has a board comprising a majority of business leaders. The London Economic Action Partnership which is partially in charge of the economic development strategy of London and which manages European,

\footnotetext{
${ }^{3}$ On this specific aspect, see the special issue of Territory, Politics, Governance, 4, 2016
} 
national and local funds for that purpose is also a public-private partnership whose board must legally be composed by at least $50 \%$ of business people and its deputy chair must be a business leader.

New York is also a case where the involvement of business is particularly significant in governance structures. Although in many instances one does not find public-private partnerships as in the UK, the presence of businessmen is nevertheless important in decision making bodies and in planning and strategic organizations. For instance, the board of the Port Authority of New York and New Jersey, which is the agency in charge of the management and development of the most important transport facilities of the metropolitan area as well as a real estate developer, is chaired by a business leader and comprises a majority of persons coming from the private sector (real estate, biotech, ICT). The same goes for the Empire State Development Corporation (ESDC), the State of New York development agency with a lot of development projects in the metropolitan area whose board comprises several important business leaders.

But the private sector is also present in a myriad of councils and committees, with indirect decision making status but which nevertheless can be used to influence strategies and policy making. This is once again the case in London where business associations like London First ${ }^{4}$ or the City of London Corporation ${ }^{5}$ are consulted in the production of some of the Mayor' strategies (skills, transport, economic development). Some important business leaders have also served as advisors to the Mayor. In New York, the Partnership for New York City (PYNC), one of the leading business associations of the city representing the largest firms (banks, media, real estate), has been involved in several economic development councils along with other private business people.

This is also the case in the Paris Ile de France area where the regional president has constituted a new body, the Strategic council for employment and attractiveness, an advisory committee composed of 25 most influent business leaders. Another example is the metropolitan area of Toronto where the private sector is actively involved in structures like the Greater Toronto Marketing Alliance, a public-private partnership acting as an inward investment agency, or the Greater Toronto Civic Action Alliance, another public-private structure whose mission is 'to be a developer of broad civic leadership creating collaborative solutions to unresolved regional challenges'. Today, Civic Action is chaired by a high rank executive of Deloitte, one of the leading world consulting firms. In Tokyo, business is often associated with other players such as the local authorities and State administrations in advisory councils like the Capital Region Forum (Saito, 2012).

If one can find examples of private sector involvement and influence in the governance of megacities, the panorama must however be more nuanced because this involvement and this influence also largely depend on historical, political and institutional factors which are specific to countries and cities.

In many countries (France, Germany, Japan, South Korea, etc.), the history and the political culture do not favour a significant participation of the private sector in the governance of cities (d'Albergo, Lefèvre and Ye, 2018). In France, as in several other continental European countries such as Spain or Italy, the governance of territories is marked by a strong influence of a neo-corporatist system (Schmitter, 1974). If the private sector is invited to participate in governance structures, it is through specific organizations, which hold very often a public status, such as the chambers of commerce. In these governance structures, be they strategic or operational, the public sector is dominant and the private sector usually occupies a marginal or a minority position. It may or not be part of the decision making, this depending of the openness of public authorities to the influence of business. Only in some rare instances, can the neo-corporatist system give a strong voice to the private sector such as in Madrid in the late 1990s and early 2000s whose governance system has been identified as a mesocorporatist one (Rodriguez-Alvarez, 2002).

\footnotetext{
${ }^{4}$ London First is a business leadership group comprised of around 200 members who represent London's leading businesses. Together, London First's members account for approximately $25 \%$ of the GDP of the city. ${ }^{5}$ City of London Corporation: the local authority covering the financial district of London. Its council is in majority elected by firms.
} 
In Japan or in South Korea, the system of the developmental State, although being eroded according to some scholars (Saito, 2012), does not permit a strong involvement of private players at the local level. Here the State and later some powerful local authorities such as the Tokyo Metropolitan Government (TMG) dominate the governance structures. True, the private sector is very often closely associated to reflections and sometimes decisions but as A. Saito (2012, p 212) puts it regarding Tokyo : 'Tokyo has a significant concentration of HQs of big business and transnational corporations. Their influence on local and regional issues has been, however, rather limited...Their role is rather passive in terms of policy making ». And this is so because «business political activities are usually targeted at national officialdom because this is where power is concentrated. » (Kantor et al, 2012, quoting Saito, p 258).

Another important element regarding the involvement of the private sector in the governance of megacities has to do with its organization. As a whole, the private sector will be more able to play a significant role if it is efficiently organized and at the 'proper' scale, i.e. the metropolitan/regional level. This is not often the case as in many urban areas (New York, Paris, Rome, Tokyo for instance) the private sector is very much fragmented and sometimes conflicting. As such it is not able to speak with a strong voice and is not audible by other players. This situation is in sharp contrast with cities like London or Madrid where the private sector is organized in a relatively small number of structures, at the regional or metropolitan level, which allows business to be a more reliable interlocutor of public authorities (Lefèvre, 2011).

Therefore when looking at a worldwide panorama, the picture is more nuanced. If we can conclude at a somewhat more visibility of the private sector in the governance of megacities, this visibility hides very different situations. In the Anglo-American world, there is more porosity between the public and the private spheres. The place assigned to private firms in policy making and in the management of public corporations is more significant because it is politically and socially more accepted and even legitimate. This does not seem to be the case outside the Anglo-Saxon world. Here, the relationships between the public and the private sectors are structured by national and local political cultures which give a less important role to private firms (and their associations). This situation may be changing but we need more empirical research to be able to substantiate this hypothesis.

\section{The role and place of population and civil society : new but marginal actors}

The involvement of people and civil society in the governance of cities may take several forms. Direct individual participation is generally done through the use of local democracy instruments like referenda or initiatives. Collective involvement is exercised by councils and committees gathering citizens and/or their organizations ; they could be ad-hoc, i.e. specific to policy sectors or projects, or more general like neighbourhood councils.

The involvement of people and civil society has gained momentum in the last two decades and can be captured with the notion of empowerment, a process by which the population is given more access to power through its participation in policy making. International organizations like the OECD, UNHabitat, the European Commission or the World Bank have largely contributed to put citizen participation in the governance of megacities in the agenda of many countries and cities. In 2001, the OECD published a report 'Cities for citizens : improving metropolitan governance' which established the OECD good governance principles, among which citizen participation because 'given the growing diversity and size of metropolitan areas, governance must allow for the participation of civil society, social partners involved in the metropolitan area' ( $p$ 19). A few years later, UN-Habitat published the Good urban governance principles in the framework of the Global Campaign on Urban Governance. Citizen participation is put forward as one of these principles because 'it is a key element in promoting transparency and accountability'. As such, 'citizens must be empowered to participate effectively in decision making processes'. To achieve this goal these international organizations promote the use of instruments such as urban referenda, development councils or neighbourhood advisory committees. 
Although citizen involvement in urban affairs had been widely used at the local level in countries where participative democracy is strong such as the United States or Switzerland, it has significantly developed in the more recent period in a vast number of States. Indeed, many national governments (France, Germany, Italy for instance) have enacted laws allowing and sometimes imposing institutional instruments of direct participative democracy at the city level such as neighbourhood councils or referenda (UN-Habitat, European Commission, 2016).

However, the various experiences which can be observed in cities show that the involvement of people in their governance take place at the local (i.e. neighbourhood or municipal) levels and that the metropolitan scale is seldom concerned. In fact, experiences of citizen participation at the metropolitan level or at scales larger than the municipal one are quite few. For example, one can cite the innovative experience of the Metropolitan Agora in Montreal. Established in 2013, the Metropolitan Agora is a two day event which takes place every two years. Its purpose is to collect the ideas and proposals of citizens regarding the monitoring and implementation of the metropolitan Sustainable Development Plan published in 2012. The Metropolitan Agora is managed by a board comprising 16 people ( 8 elected officials and 8 citizens) co-chaired by one councillor of Montréal and one citizen, which is in charge of preparing the event with civic organizations. The second Agora occurred in 2015 and the third one took place in October 2018. This last one had in charge the elaboration of proposals to be included in the next Development Plan of the metropolitan area running over the period 2019-2023.

Other megacities have established similar tools such as the Citizen Committee for the Seoul Development Plan or the various citizens forums for the Sydney master plan (Lefèvre, Aldhuy and Terral, 2016). These are interesting experiences which show the growing importance attributed to citizen participation in public affairs by some metropolitan authorities. However, they fall short of 'empowering' the population of cities because these processes and their structures largely remain consultative and only address very specific matters.

Two major reasons may explain the weak, not to say marginal, role played by citizens and their organizations in the governance of megacities. The first one concerns national political cultures and their embedment in the institutional organization of the country. In many countries, the political system is dominated by a political conception of power based on representative democracy. Although this can be said of most countries, this domination may be more or less important and can give a more or less space to participative democracy. However, except in very specific and rare cases (e.g. Switzerland or the United States), participative democracy remains a weak dimension of the polity. In many countries (UK, France, Italy, Japan, etc.), participative democracy is conceived, at best, as a supplement to representative democracy. In such a context, the involvement of citizens in local governance is therefore minimal in decision making because it is considered less legitimate than the power given to representatives of the population by local or national elections. This explains why instruments of direct democracy like referenda are generally consultative.

The second reason has to do with the population and civil society itself. Generally speaking, civil society is rarely organized at the metropolitan scale. When it is organized at that level, it is usually because the initiative has come from national governments or metropolitan authorities. This is the case in France with the metropolitan councils of development which have been established by the National Sustainable Act of 1999. This is also the case in Stuttgart where the metropolitan authority, the Verband Regio Stuttgart (VRS), has created several forums regarding religions, youth or women. But all these structures are relatively weak and only advisory bodies. The quasi-absence of metropolitan organizations representing civil society is largely due to the fact that the population and its structures of representation have not felt very much concerned by metropolitan wide issues and has focused primarily on very local (neighbourhood, sometimes municipal) problems (Lefèvre, 2012). This may change in the near future with the emergence of questions such as climate change or social and territorial inequalities for which the metropolitan scale seems to be more relevant for policy making but it stills remains an hypothesis.

\section{Conclusion}


This rapid panorama of the governance of megacities shows that the key point regarding their governance, that is the capacity of their system of players to produce collective action, has become more difficult, notably because of the increasing number of players, the complexity of the system of actors, its polycentricity and confllictuality. The four major processes identified (globalisation, decentralisation, liberalization and European integration for European cities) have each contributed to this situation as it has been shown.

However, if these four processes have significantly transformed the governance of megacities, strong elements and factors of stability remains which largely explains why megacities may differ in their governance from one country to the other, one city to the other. First, if the State remains strong in most instances and if it plays a different role today than before, its presence and its modes of action largely vary according to the history of the country and the relations between State and civil society. Second, if the involvement of private players may be more visible and in some cases more significant, it still depends of pre-existing elements like the national and local political cultures which assign a more or less legitimate place and role to these players in the governance of cities. Finally, if the call for more important civil society and citizens participation can be heard in most countries and cities, its effectivity once again depends on national and local cultures which give a more or less important place to direct democracy with respect to representative democracy. 


\section{References}

D'Albergo, E, Lefèvre, C. and L. Ye (2018), 'For a Political Economy of metropolitan scale : the role of public-private relations, Territory, Politics, Governance, 6, 2, pp 182-188

Bon, B and L. Kennedy, (2018), 'Contrasting the Spatial and Political Dimensions of Rescaling in Metropolitan Delhi', in Gross, J, Gualini, E and L. Ye, Constructing Metropolitan Space: Actors, Policies and Processes of Rescaling in World Metropolises, Routledge

Brenner, N. (2004), New State spaces, urban governance and the rescaling of Statehood, Oxford University Press

Brenner, N, Peck, J and N. Theodore (2010), 'Variegated neo-liberalization : Geographies, modalities, pathways', Global networks, 10, 2, pp 182-222

Epstein, R. (2009), 'Après la territorialisation, le gouvernement à distance' in M. Vanier (ed),

Territoire, territorialité, territorialisation : controverses et perspectives, Rennes, Presses

universitaires de Rennes, pp 131-140

Halbert, L. and K. Attuyer (2016), 'The financialization of urban production', Urban Studies, Special Issue, $53,7$.

Kantor, P. et al (2012), Struggling giants : City region governance in London, New York, Paris and Tokyo, University of Minnesota Press

Kubler, D. et C. Lefèvre, (2018), 'Megacity governance and the State', Urban Research and Practice, 11,4 , pp 378-395

Lefèvre, C. (1998), 'Metropolitan government and governance in Western countries, a critical review', International Journal of Urban and regional Research, 22, 1, pp 9-25.

Lefèvre, C. (2011), The involvement of economic actors in urban strategies in Europe, Governance and Globalization, WP series 25, pp 1-20, Sciences Po in China

Lefevre, C. (2012) 'The improbable metropolis : Decentralization, local democracy and metropolitan areas in the Western world', in Saixas, J and A. Albet (Eds), Urban Governance in Southern Europe, Routledge

Lefèvre, C, Aldhuy, J and L. Terral (2016), 'Quelle stratégie de positionnement de l'Ile-de-France dans un système économique mondial de plus en plus intégré et concurrentiel ?' report for the Regional Council of Ile de France, Conseil Régional d'Ile de France

LeGalès, P. (2003), European Cities, social conflicts and governance, Oxford University Press,

LeGalès, P. (2016), 'neo-liberalism and urban change : stretching a good idea too far', Territory,

Politics, Governance, 4, 2, pp 154-172

Logan, J. and H. Molotch, (1987), Urban Fortunes, the Political Economy of Place, University of California Press,

Moulaert, F, Rodriguez, A and E. Swyngedouw (2003), The Globalized city : Economic restructuring and social polarization in European cities, Oxford University Press, Oxford

OECD, (2001), Cities for citizens : improving metropolitan governance, OECD, Paris.

OECD, (2012), Redefining 'urban', a new way to measure metropolitan areas, OECD, Paris

OECD, (2015), Governing the city, OECD, Paris

OECD, (2015), The Metropolitan century, OECD, Paris

Pinson, G. and C Morel-Journel (2017), Debating the neo-liberal city, Routledge

Regional Plan Association (RPA) (2017), Fourth Regional Plan, RPA, New York

Rodriguez-Alvarez J (2002), in Jouve, B. and C. Lefèvre, Métropoles ingouvernables, Elsevier, Saito, A. (2012), 'The Tokyo City Region' in Kantor et al, Struggling giants : City region governance in London, New York, Paris and Tokyo, pp 193-240

Schmitter, P. (1974), 'Still the century of corporatism', The Review of Politics, 36, 1, pp 85-131

Stone, C. 1993), 'Urban regimes and the capacity to govern : a political economy approach, Journal of Urban Affairs, 15, 1, PP 1-28

Travers, T. (2003), The politics of London, governing and ungovernable city, Palgrave, UN-Habitat and European Commission (2016), The State of European Cities,

Ye, L. (2014). 'State-led metroplitan governance in China: making integrated city-regions.' Cities 4, pp 200-208. 
Zérah, M.H. (2014) 'Transforming Mumbai' or the Challenges of Forging a Collective Actor', in Lorrain, D. (Ed) (2014), Governing megacities in emerging countries, Routledge. 